\title{
Estimation of Organic Pollution of the Jinyaoshi Lake Based on the Diatom Assemblage of the Lake Sediments
}

\author{
Jing Fang ${ }^{1 *}$, Yufei Liu ${ }^{1}$, Tianjiao Wang ${ }^{1}$, Xia Yan ${ }^{1}$, Yang Shuo ${ }^{1}$, Liping Zhang ${ }^{1}$, Yinghui Qu ${ }^{1}$ \\ ${ }^{1}$ School of Geography and Environmental Science, Tianjin Normal University, Tianjin 300387, China
}

\begin{abstract}
From 2015 to 2019, samples of surface mud from the bottom of the artificial lake in Tianjin Normal University were collected for diatom analysis and identification in May and June. 1296 diatoms were identified and divided into 25 species. DAIpo (Diatom Assemblage Index to organic water pollution) was calculated: 56 in 2015, 76 in 2017, 58 in 2018 and 63 in 2019. In 2017, it was $\beta$-oligosaprobic, and in 2015, 2018 and 2019, it belonged to $\alpha$-oligosaprobic. The Jinyaoshi Lake is an artificial lake where groundwater is exposed by artificial excavation, and its water source mainly comes from groundwater, then by precipitation. It shows that the pollution degree of the Jinyaoshi Lake was not serious since 2015, and its pollution level was $\alpha$ or $\beta$-oligosaprobic.
\end{abstract}

\section{Introduction}

Diatoms are abundant in water (including lakes, rivers, oceans, etc.) and are easy to sample. Diatoms are of great significance to the environment. It is a great indicator of environmental assessment. Watanabe, T. et al. (1986) published DAIpo, a comprehensive evaluation value of organic pollution based on attached diatoms. Diatoms were divided into three groups: saprophilous taxa, eurysaprobic taxa, and saproxenous taxa. The relative percentages of the three species are calculated to obtain the water pollution degree, DAIpo. By calculating the DAIpo, the organic pollution degree of water can be numerically calculated, and the pollution status of different water or different periods of the same water can be compared (Watanabe,et al 1986a,b,1988; Asai and Watanabe,1995). In this study, Watanabe and other methods were used to evaluate the pollution degree of artificial lake in Tianjin Normal University in the southwest of Tianjin in different years.

\section{Materials and methods}

The West Coast Plain of Bohai Bay is located in the subsidence zone of North China which has been sinking continuously since Cenozoic. Most of the land on the plain is lower than $2.5 \mathrm{~m}$, the terrain is flat, and the slope is only $1 / 20000 \sim 1 / 30000$, which is the lowest and flat place in the coastal area of North China. The surface is covered by extensive Quaternary coastal alluvial, lack deposits or marine deposits. The research area is located in the Jinyaoshi Lake of Tianjin Normal University in the southwest of Tianjin(Fig. 1).

From 2015 to 2019, samples of surface mud from the bottom of the Jinyaoshi Lake in Tianjin Normal
University were collected for diatom analysis and identification in May and June. Diatom slices were made in the laboratory and identified under 400 times optical microscope. More than 200 diatoms were counted in each sample, and the percentages of diatoms of different species and genera were calculated, the diatom map was made. According to the tolerance of different diatoms to the pollution, the turbidity index was calculated to evaluate the water pollution degree. Diatom was identified according to Watanabe et al. (2005). Diatoms were divided into saproxenous taxa (A) and saprophilous taxa (B), and then DAIpo were calculated according to their proportions.

$$
D A I p o=50+1 / 2(A-B)
$$

A: The sum of the relative frequencies (\%) of all saproxenous taxa $(*)$ appearing at the survey site.

B: The sum of the relative frequency $(\%)$ of all saprophilous taxa (\#) appearing at the survey site.

If the constituents are all saproxenous taxa $(*)$, then DAIpo $=100$; if the constituents are all saprophilous taxa $(\#)$, then DAIpo $=0$; if the constituents are all widely adaptable species, then DAIpo $=50$.

The criteria of water quality determined by DAIpo are shown in Table 1.

* Corresponding author: mdfangjing@163.com 


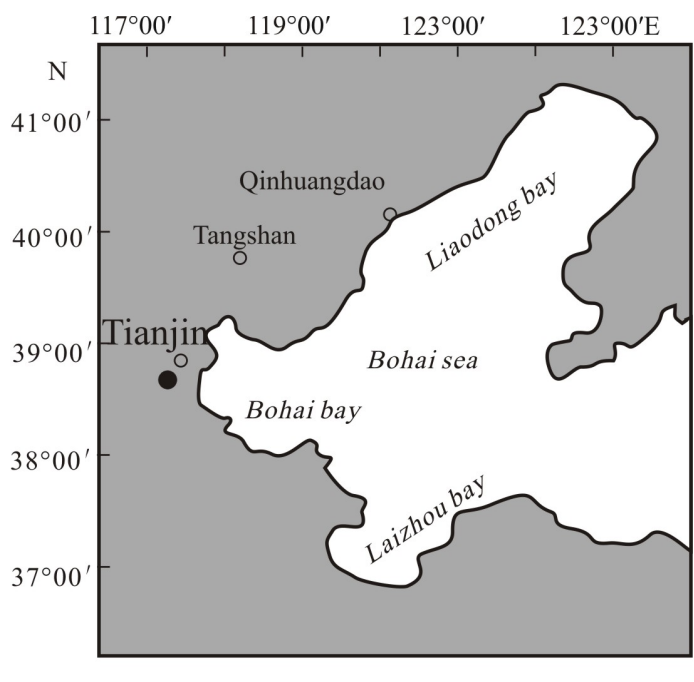

- Sampling point

O place name

Fig. 1. Map of sampling points in study area

Table 1. Evaluation standard of water quality by DAIpo.

\begin{tabular}{|c|c|c|}
\hline DAIpo & BOD(mg/L) & Pollution level \\
\hline $100-86$ & $0-0.625$ & xenosaprobic \\
\hline $85-71$ & $0.625-1.25$ & $\beta$-oligosaprobic \\
\hline $70-51$ & $1.25-2.5$ & $\alpha$-oligosaprobic \\
\hline
\end{tabular}

\begin{tabular}{|c|c|c|}
\hline $50-31$ & $2.5-5.0$ & $\beta$-mesosaprobic \\
\hline $30-16$ & $5.0-10.0$ & $\alpha$-mesosaprobic \\
\hline $15-0$ & $>10$ & polysaprobic \\
\hline
\end{tabular}

\section{Results and discussion}

\subsection{Diatom assemblage}

According to the analysis of diatom in the surface mud of the Jinyaoshi Lake in Tianjin Normal University, the diatom assemblage in 2015 was mainly Nitzschia subacicularis(55.4\%)- Aulacoseira ambigua(11.2\%)Navicula paucivisitata(8.4\%); Rhopalodia gibba(30.2\%)- Encyonema minutum(15.7\%) - Amphora fogediana(15.2\%)- Fragilaria capucina(14.7\%); Navicula paucivisitata (21.2\%) - Fragilaria neoproducta (18.6\%)- Nitzschia perminuta(15.7\%) - Nitzchia nana(13.1\%); Navicula paucivisitata (27.4\%) Achnanthes minutissima (10.9\%) - Fragilaria neoproducta (10.6\%)(Tab. 2, Fig. 2).

Table 2. Identification of diatom in surface mud of the Jinyaoshi Lake.

\begin{tabular}{|c|c|c|c|c|c|c|c|c|c|c|}
\hline & & & \multicolumn{2}{|c|}{2015} & \multicolumn{2}{|c|}{2017} & \multicolumn{2}{|c|}{2018} & \multicolumn{2}{|c|}{2019} \\
\hline & & & Quantity & Percentage/\% & Quantity & Percentage/\% & Quantity & Percentage/\% & Quantity & Percentage/\% \\
\hline number & species & & 296 & 100 & 394 & 100 & 236 & 100 & 350 & 100 \\
\hline 1 & $\begin{array}{l}\text { Diploneis } \\
\text { elliptica }\end{array}$ & $*$ & 5 & 1.7 & 2 & 0.5 & 1 & 0.4 & 9 & 2.6 \\
\hline 2 & $\begin{array}{c}\text { Fragilaria } \\
\text { neoproducta }\end{array}$ & $*$ & 10 & 3.4 & 15 & 3.8 & 44 & 18.6 & 37 & 10.6 \\
\hline 3 & $\begin{array}{l}\text { Amphora } \\
\text { fogediana }\end{array}$ & $*$ & 6 & 2.0 & 60 & 15.2 & 7 & 3.0 & 19 & 5.4 \\
\hline 4 & $\begin{array}{c}\text { Fragilaria } \\
\text { capucina }\end{array}$ & $*$ & 13 & 4.4 & 58 & 14.7 & 17 & 7.2 & 24 & 6.9 \\
\hline 5 & Navicula cincta & $*$ & 7 & 2.4 & & & & & 15 & 4.3 \\
\hline 6 & $\begin{array}{l}\text { Gomphonema } \\
\text { pseudokunoi }\end{array}$ & $*$ & 2 & 0.7 & 9 & 2.3 & & & & \\
\hline 7 & $\begin{array}{c}\text { Gomphonema } \\
\text { eriense }\end{array}$ & $*$ & & & 2 & 0.5 & & & & \\
\hline 8 & $\begin{array}{c}\text { Encyonema } \\
\text { minutum }\end{array}$ & $*$ & & & 62 & 15.7 & & & & \\
\hline 9 & Nitzchia nana & \# & 7 & 2.4 & 3 & 0.8 & 31 & 13.1 & 13 & 3.7 \\
\hline 10 & $\begin{array}{c}\text { staurosirella } \\
\text { lapponica } \\
\end{array}$ & \# & & & & & & & 1 & 0.3 \\
\hline 11 & $\begin{array}{c}\text { Nitzschia } \\
\text { subacicularis }\end{array}$ & & 164 & 55.4 & 10 & 2.5 & & & 23 & 6.6 \\
\hline 12 & $\begin{array}{c}\text { Aulacoseira } \\
\text { ambigua }\end{array}$ & & 36 & 12.2 & 7 & 1.8 & 20 & 8.5 & 12 & 3.4 \\
\hline 13 & $\begin{array}{c}\text { Navicula } \\
\text { paucivisitata }\end{array}$ & & 25 & 8.4 & 11 & 2.8 & 50 & 21.2 & 96 & 27.4 \\
\hline 14 & $\begin{array}{l}\text { Achnanthes } \\
\text { minutissima }\end{array}$ & & 9 & 3.0 & 6 & 1.5 & 4 & 1.7 & 38 & 10.9 \\
\hline 15 & $\begin{array}{c}\text { Gomphonema } \\
\text { grunowii }\end{array}$ & & 3 & 1.0 & & & & & & \\
\hline 16 & $\begin{array}{c}\text { Punctastriata } \\
\text { linearis }\end{array}$ & & 5 & 1.7 & & & & & & \\
\hline 17 & $\begin{array}{l}\text { Cyclotella } \\
\text { stelligera }\end{array}$ & & 2 & 0.7 & 1 & 0.3 & 16 & 6.8 & 5 & 1.4 \\
\hline 18 & $\begin{array}{l}\text { Nitzschia } \\
\text { perminuta }\end{array}$ & & 2 & 0.7 & 4 & 1.0 & 37 & 15.7 & 22 & 6.3 \\
\hline
\end{tabular}




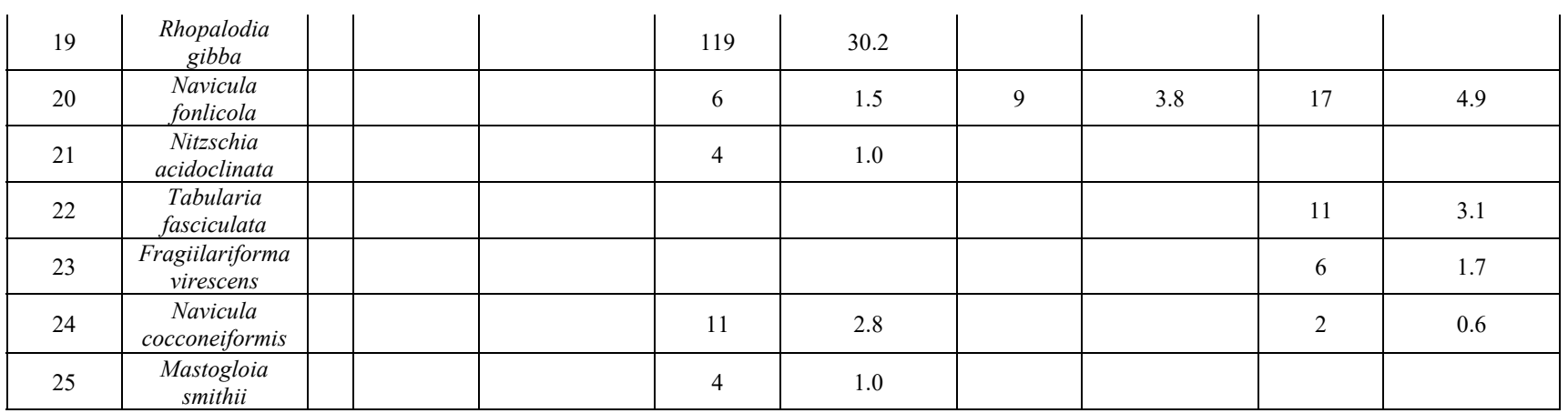

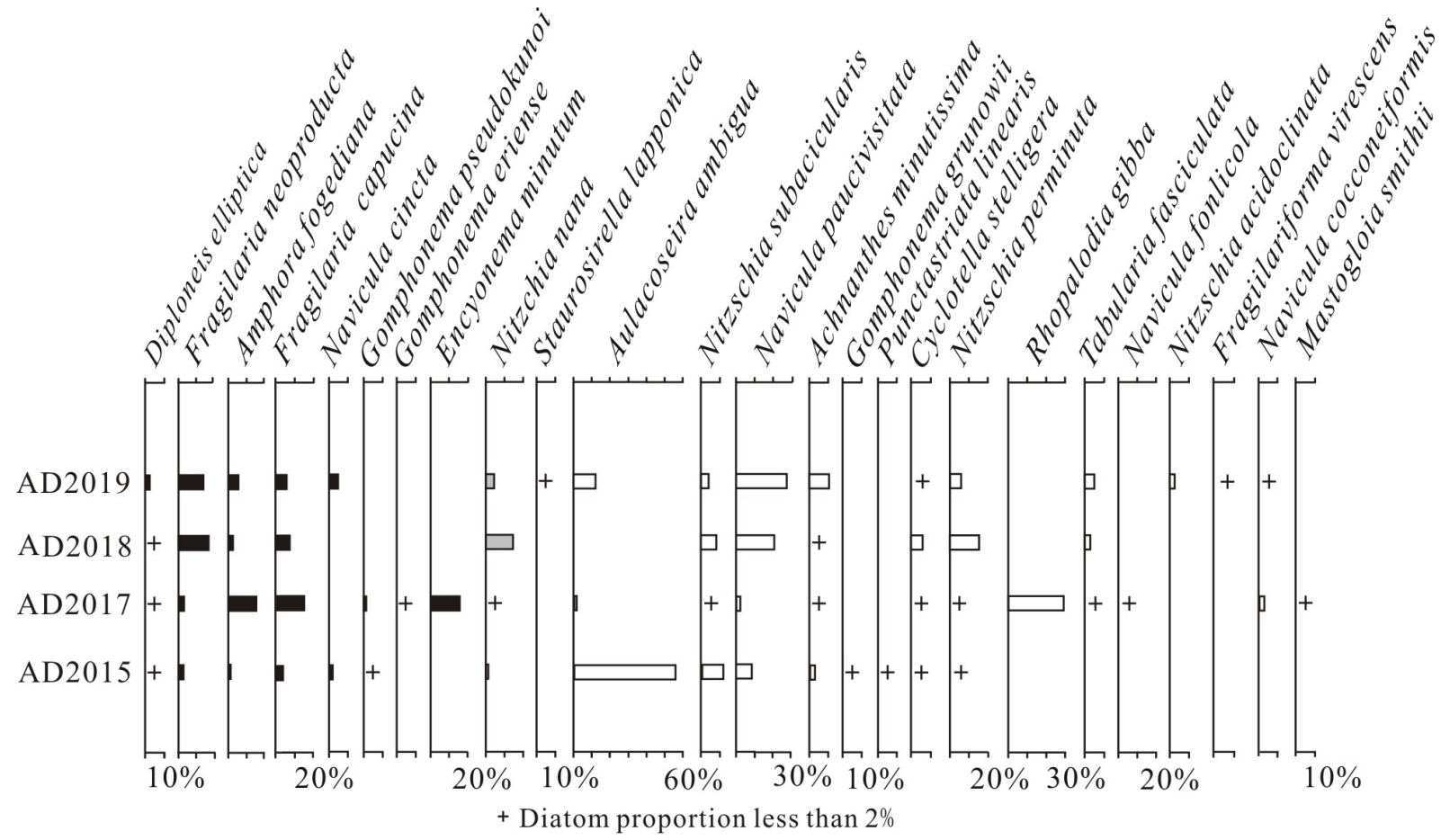

Saproxenoustaxa

$\square$ Saprophiloustaxa

Indifferenttaxa

Fig. 2. Results of diatoms in surface mud of the Jinyaoshi Lake.

\subsection{Evaluation of water quality of the Jinyaoshi Lake}

Diatom analysis showed that 25 species of diatoms were found in the surface mud of the Jinyaoshi Lake in 2015, 2017, 2018 and 2019. There are 8 saproxenous taxa, Diploneis elliptica, Fragilaria neoproducta, Amphora fogediana, Fragilaria capucina, Navicula cincta, Gomphonema pseudokunoi, Gomphonema eriense and Encyonema minutum, 2 saprophilous taxa, Nitzchia nanad and staurosirella lapponica, and 15Widely adaptable species, Nitzschia subacicularis, Aulacoseira ambigua, Navicula paucivisitata, Achnanthes minutissima, Gomphonema grunowii, Punctastriata linearis, Cyclotella stelligera, Nitzschia perminuta, Rhopalodia gibba, Navicula fonlicola, Nitzschia acidoclinata, Tabularia fasciculata, Fragiilariforma virescens, Navicula cocconeiformis and Mastogloia smithii .

DAIpo was 56 in 2015, 76 in 2017, 58 in 2018 and 63 in 2019. It can be seen that in 2017 , it was $\beta$ oligosaprobic,

and in 2015, 2018 and 2019, it was $\alpha$-oligosaprobic. It shows that the pollution level was not serious in these four years (Tab. 3).

Table 3. Water quality evaluation of the Jinyaoshi Lake.

\begin{tabular}{|c|c|c|c|c|c|c|c|}
\hline year & $\begin{array}{c}\text { Number of } \\
\text { frustules }\end{array}$ & Species & $\begin{array}{c}\text { Saproxenous } \\
\text { taxa (\%) }\end{array}$ & $\begin{array}{c}\text { Saprophilous } \\
\text { taxa (\%) }\end{array}$ & $\begin{array}{c}\text { Indifferent } \\
\text { taxa (\%) }\end{array}$ & DAIpo & Water quality \\
\hline 2015 & 296 & 15 & 6 & 1 & 8 & 56 & $\alpha$-mesosaprobic \\
\hline 2017 & 394 & 19 & 7 & 1 & 11 & 76 & $\beta$-mesosaprobic \\
\hline 2018 & 236 & 11 & 4 & 1 & 6 & 58 & $\alpha$-mesosaprobic \\
\hline 2019 & 350 & 17 & 5 & 2 & 10 & 63 & $\alpha$-mesosaprobic \\
\hline
\end{tabular}




\section{Conclusions}

Based on diatom analysis of the surface mud of the Jinyaoshi Lake in Tianjin Normal University, the DAIpo obtained in 2015 and 2017-2019 was calculated, showing that the average value is 63 . The pollution level belongs to $\alpha$-oligosaprobic, indicating that the pollution is not serious.

\section{Acknowledgements}

This research was financially supported by the Tianjin Natural Science Foundation (18JCYBJC91100).

\section{References}

1. Watanabe T, Asai K, Houki A, Tanaka S. and Hizuka T.(1986) Saprophilous and eurysaprobic diatom taxa to organic water pollution and Diatom Assemblage Andex (DAIpo). Diatom,2 : 23-73.

2. Watanabe T, Asai K, Houki A, Tanaka S, Hizuka T,1986a.Saprophilous and eurysaprobic diatom taxa to organic water pollution and diatom assemblage index (DAIpo). Diatom, 2:22-73.

3. Watanabe T, Asai K, Houki A, 1986b. Epilithic diatom assemblage index to organic water pollution (DAIpo) and its ecological significance. Annals for Graduate School of Humanities and Sciences, Nara Women's University, 1:77-95.

4. Watanabe, T. Asai, K. and Houki, A. 1988. Biological information closely related to the numerical index DAIpo (Diatom assemblage index to organic water pollution). Diatom 4: 49-58.

5. Asai, K. and Watanabe, T. 1995. Statistic classification of epilithic diatom species into three ecolgical groups relating to organic water pollution. (2) Saprophilous and saproxenous taxa. Diatom 10:35-47.

6. Watanabe T, Ohtsuka T, Tuji A, Houki A, 2005. Picture book and ecology of the freshwater diatoms. Uchida Rokakuho Publishing Company, Tokyo. 666. 